\title{
Tricuspid Atresia 18 Years Post Glenn: Is Fontan Necessary in All Cases?
}

\author{
S Williams-Phillips
}

\begin{abstract}
Tricuspid atresia is a rare cyanotic congenital heart disease, first described by Kreysig (1817), with an incidence of $1 \%$ to $5 \%$. It is incompatible with longevity without surgical intervention. Glenn (1958) was successful in using a superior vena cava to right pulmonary artery anastomosis. Fontan (1958) was successful in separating the right and left cardiac circulation; this is the surgical method of choice, with death of $17 \%$ by 20 years of age. The Fontan circulation has burdens of multisystem abnormalities, including ventricular dysfunction (72\%), dysrhythmias (40\%) and renal, hepatic, gastrointestinal and pulmonary complications. The index case is the oldest documented report of tricuspid atresia with rudimentary right ventricle and concordant ventriculo-arterial connections, 18 years post Glen only, from two years of age. She is asymptomatic, of high intellect, never used medications and is now functioning at New York Heart Association (NYHA) I-II at 20 years of age. Her survival and function was secondary to an innate large atrial and ventricular communication with normal left ventricle, mitral, aortic and pulmonary valves, indicating Fontan may not be needed in all structural anatomic cases of tricuspid atresia.
\end{abstract}

Keywords: Glenn procedure, pulmonary artery, superior vena cava, tricuspid atresia

\section{Atresia Tricúspide 18 Años Post-Glenn: ¿Es Fontan Necesario en Todos los Casos?}

\author{
S Williams-Phillips
}

\begin{abstract}
RESUMEN
La atresia tricúspide es una rara enfermedad cardíaca congénita cianótica, primeramente descrita por Kreysig (1817), con una incidencia de 1\% a 5\%. Es incompatible con la longevidad sin una intervención quirúrgica. Glenn (1958) tuvo éxito en el uso de una anastomosis vena cava superior a la arteria pulmonar derecha. Fontan (1958) tuvo éxito en separar la circulación cardiaca derecha y la izquierda. Este es el método quirúrgico de elección, con un 17\% de muertes a los 20 años de edad. La circulación de Fontan tiene cargas de anormalidades multi-sistémicas, incluyendo disfunción ventricular (72\%), arritmias (40\%), y complicaciones renales, hepáticas, gastrointestinales y pulmonares. El caso indice es el reporte más viejo documentado de la atresia tricúspide con ventrículo derecho rudimentario y conexiones ventrículo-arteriales concordantes, 18 años post-Glen solamente, desde dos años de edad. Se trata de una paciente asintomática, de alto intelecto, nunca usó medicamentos, y se halla ahora trabajando en la Asociación Cardiológica de Nueva York (NYHA) I-II a los 20 años de edad. Su supervivencia y función fue secundaria con respecto a una gran comunicación innata atrial y ventricular con el ventrículo izquierdo normal, las válvulas mitrales, aórticas y pulmonares, que indican que el procedimiento Fontan puede no ser necesario en todos los casos anatómicos estructurales de atresia tricúspide.
\end{abstract}

Palabras claves: Procedimiento de Glenn, arteria pulmonar, vena cava superior, atresia tricúspide

West Indian Med J 2015; 64 (3): 294

From: Andrews Memorial Hospital, TAI Wing, 27 Hope Road, Kingston 10, Jamaica, West Indies.
Correspondence: Dr S Williams-Phillips, Andrews Memorial Hospital, TAI Wing, 27 Hope Road, Kingston 10, Jamaica, West Indies. E-mail: sandrap@cwjamaica.com 


\section{INTRODUCTION}

Tricuspid atresia is a rare cyanotic congenital heart disease, first described by Kreysig (1817), and first categorized by Kuhne (1906) into three types. It has an incidence of $1 \%$ to $5 \%$, and is incompatible with longevity without surgical intervention $(1,2)$. Glenn $(1958)$ was successful in using a superior vena cava to right pulmonary artery anastomosis, which has been revised from classical to the bidirectional Glenn $(1,2)$. Fontan (1958) was successful in separating the right and left cardiac circulation, without subpulmonary ventricular assisted pumping, and this is the surgical method of choice (2), with reduced life expectancy and death of $17 \%$ by age 20 years. The Fontan circulation has well-documented burdens of heart failure, thrombo-emboli-coagulation abnormalities (15-25\%), dysrhythmia (20-40\%), sudden death, renal, hepatic dysfunction and cirrhosis ( $75 \%$ autopsies), and gastrointestinal protein losing enteropathy (3-10\%) complications. The systolic ventricular function is reduced in $27 \%$ and diastolic dysfunction in $72 \%$ with insidiously declining heart rate reserve, which is further limited by $50 \%-60 \%$ upon exertion and indicates some autonomic dysfunction. The Fontan circulation may have rare occurrences of plastic bronchitis (1-2\%), ascites and increased risk of both fetal and maternal complications. Multiple surgeries are required to complete the Fontan, with perioperative mortality now less than $2 \%$, mortality of $10 \%$ at 10 years, $17 \%$ at 20 years and $30 \%$ at 25 years $(1-3)$.

The index case was diagnosed in infancy with Type 1 tricuspid atresia with concordant atrio-ventricular connections, after presenting with cyanosis, and survived because of a common atrium and non-restrictive ventricular septal defect. Bidirectional Glenn procedure was done at two years of age and retrospectively, fortuitously, never proceeded to complete Fontan. Tricuspid atresia is the only physical abnormality, with normal mitral, aortic and pulmonary valves. She has been asymptomatic for 18 years post Glen, functioning at New York Heart Association (NYHA) I-II, suggesting there being no need for complete Fontan in specific structural anatomic types of tricuspid atresia.

\section{CASE REPORT}

The index case is a 20-year old Afro-Caribbean female with height of $165 \mathrm{~cm}$, weight of $45.2 \mathrm{~kg}$ and a body mass index of $16.6 \mathrm{~kg} / \mathrm{m}^{2}$. She has no dysmorphic features, normal ample pubertal development, pink mucous membranes, central cyanosis and mild clubbing of fingers and toes. There is no history of palpitations, jaundice or oedema. She has never taken any cardiac nor anti-failure, anti-platelet or anticoagulant medications. She is gainfully employed whilst attending a tertiary level institution part time. She takes public transportation to work and school.

Her steady state oxygen saturation is $74 \%$, blood pressure $120 / 69$, pulse rate 96 per minute with no pulse deficit and a respiratory rate of 20 per minute.

Cardiovascular examination revealed normal pulses, apex beat in $5^{\text {th }}$ left intercostal space in the mid-clavicular line, single first and normal $2^{\text {nd }}$ heart sound and a pansystolic murmur $3 / 6$ at mid left sternal border. There were no continuous murmurs, diastolic murmur and no additional heart sounds, nor signs of heart failure or pulmonary hypertension.

Haemoglobin was $14.8 \mathrm{~g} / \mathrm{dL}$ and packed cell volume was $48 \mathrm{~L} / \mathrm{L}$. She had mean corpuscular haemoglobin $(\mathrm{MCH})$ of 24 $\mathrm{p}$ (normal 27-32), mean corpuscular volume (MCV) of $77 \mathrm{fL}$ (normal 80-96) and platelets of 285 (normal 150-400). The $\mathrm{MCH}$ and MCV values were indicative of iron deficiency, in the absence of thalassemia or any other disorder causing hypochromia and microcytosis.

Urinalysis was normal with $\mathrm{pH} 6.0$ (normal 4.8-7.5), specific gravity of 1.005 (normal 1.000-1.030) and no proteins, blood, glucose, ketones, bilirubin, urobilirubin, nitrite, red blood cells, crystals, casts, amorphous deposits nor mucous threads.

Electrocardiogram showed sinus rhythm, heart rate of 90 beats per minute, left axis deviation and left ventricular hypertrophy. There was normal QRS duration, no significant ST segment anomaly, with normal $\mathrm{P}$ axis and $\mathrm{T}$ axis. Chest $\mathrm{X}$-ray showed normal cardiothoracic ratio and vascularity. There was prominence of the left atrial appendage noted on the left heart contour. There was normal ratio of right and left bronchi, laevocardia, left aortic arch and normal positioning of chest and abdominal viscera, eliminating right or left atrial isomerism.

Transthoracic echocardiography (TTE) showed situs solitus (Fig. 1), univentricular atrioventricular connection, with tricuspid valve atresia (Fig. 2), concordant ventriculo-arterial connections, with normal arrangement of great vessels. There was normal continuous flow in the superior vena cava to right pulmonary artery (Fig. 3), varying normally with respiration, in the suprasternal view. The pulmonary veins entered the leftsided atria (Fig. 2).

There was a large inter-atrial communication (Fig. 2), with normal left and right atrial appendages with no juxtaposition. There was a competent left atrioventricular valve (ie mitral valve), with trivial mitral regurgitation, no mitral stenosis and normal "E" and "A" waves in diastole (Fig. 4), with diastolic flow from the left atrium to left ventricle. There was a rudimentary anterior right ventricle (Fig. 2), with small incomplete intra-ventricular cavity with trabecular and outlet region, and normal left ventricle with left-hand topology (Fig. 2). There was a non-restrictive ventricular septal defect (VSD), extending from the trabecular to outlet interventricular septum, with a left to right flow across the VSD. Trileaflet aortic valve with left-sided aortic arch was observed with no stenosis or regurgitation, with descending aorta peak velocity of $1.1 \mathrm{~m} / \mathrm{s}$ (Fig. 5). Dimension of aortic root at the sinus of Valsalva was $2.9 \mathrm{~cm}$ and $1.6 \mathrm{~cm}$ at hinge point. The pulmonary valve originated from the right ventricle with no stenosis or regurgitation, with peak velocity of $52.6 \mathrm{~cm} / \mathrm{s}$ (Fig. 6). The left ventricular end diastolic dimension was $3.8 \mathrm{~cm}$ in parasternal short axis view and $3.2 \mathrm{~cm}$ in parasternal long axis view. 


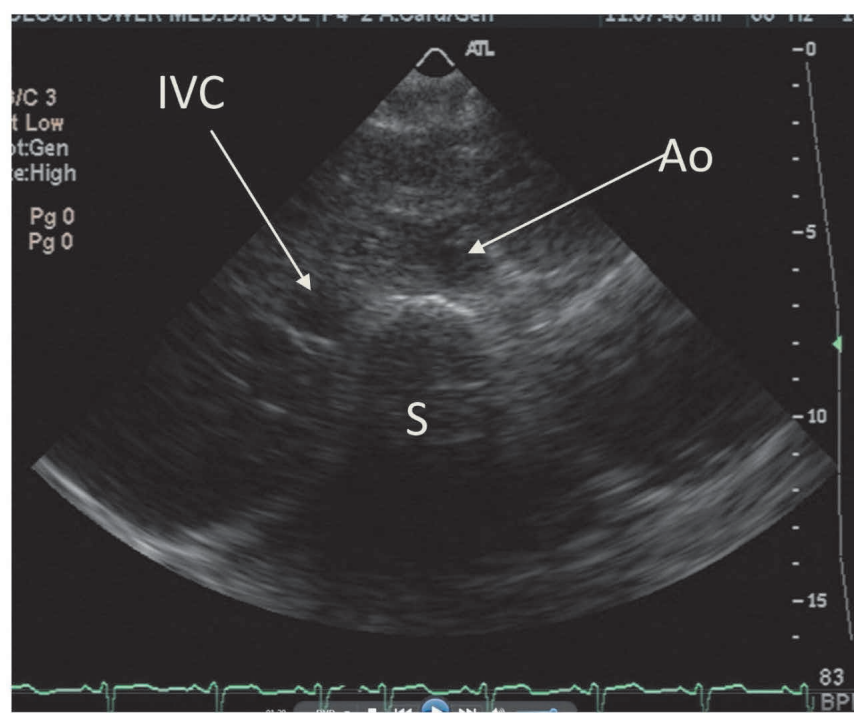

Fig. 1: Situs solitus shown with spine (S), aorta (Ao) to the left of spine and inferior vena cava (IVC) to the right of spine.

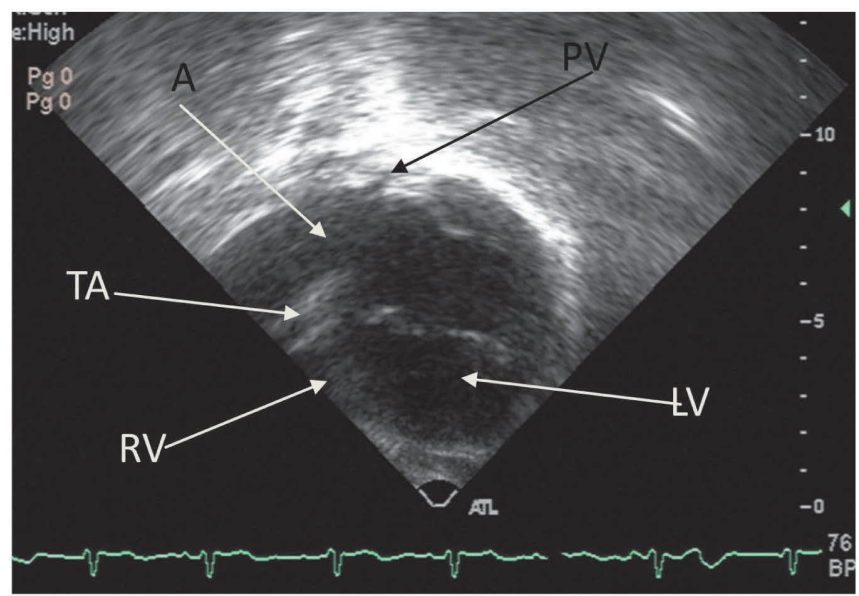

Fig. 2: Atria (A), left ventricle (LV), mitral valve open, tricuspid atresia (TA) and pulmonary vein $(\mathrm{PV})$ entering left side of atrium.

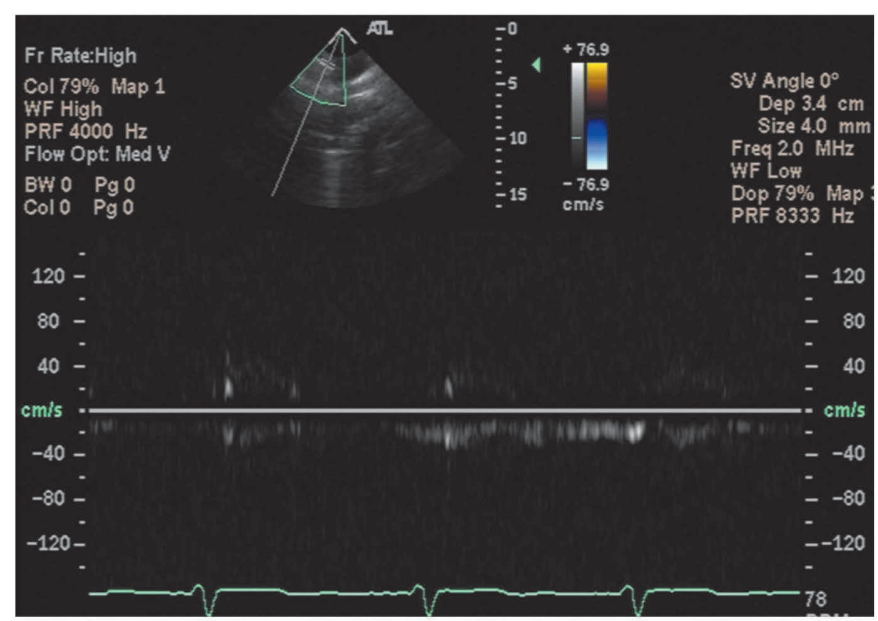

Fig. 3: Continuous superior vena cava Doppler flow varying with respiration.

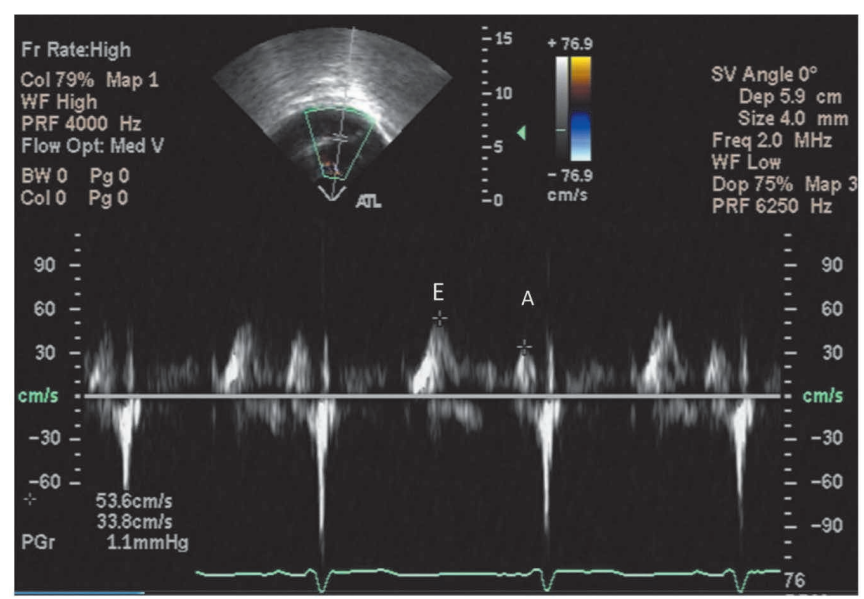

Fig. 4: Mitral valve Doppler flow with E and A wave.

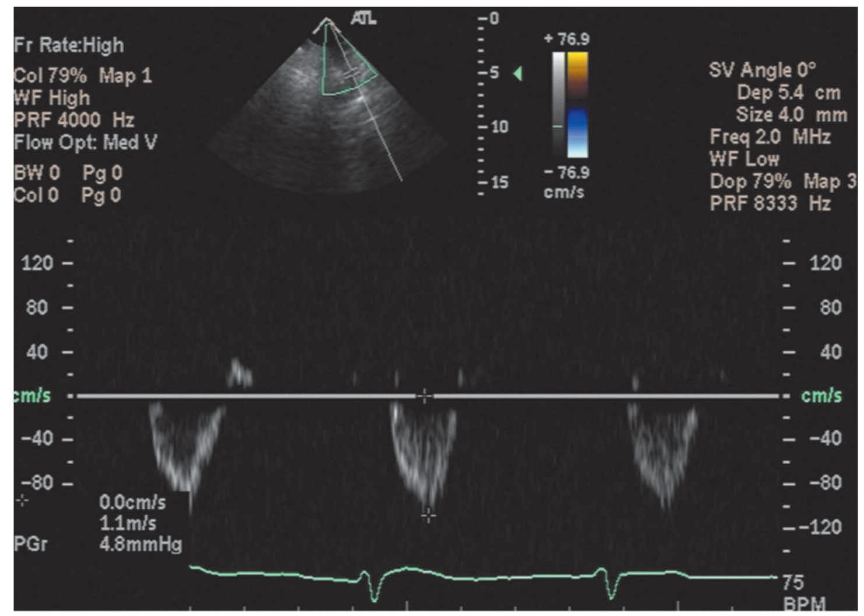

Fig. 5: Descending aorta Doppler flow $1.1 \mathrm{~m} / \mathrm{s}$.

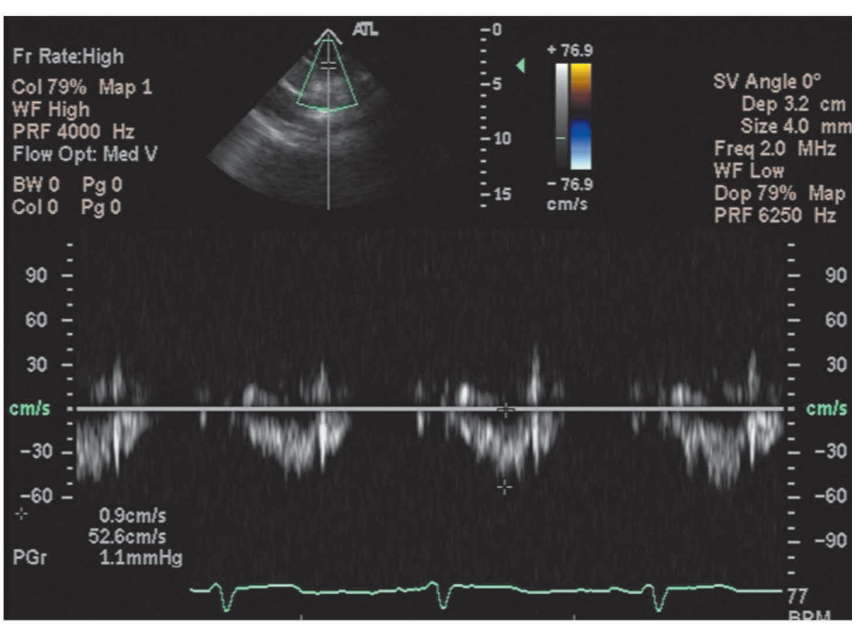

Fig. 6: Pulmonary valve Doppler $52.6 \mathrm{~cm} / \mathrm{s}$.

There was normal ventricular function with shortening fraction of $34 \%$ and ejection fraction of $66 \%$. There were no wall motion abnormalities of right or left ventricle or pericardial effusion. 


\section{DISCUSSION}

Survival and the type of surgical procedure, including B-T shunts, Glenn, Fontan, Damus-Kaye-Stansel and modified Bjork procedures, for tricuspid atresia have a direct correlation to the structural anatomy and circulatory physiology. Longevity without surgical intervention is usually not beyond the neonatal period, but those with pulmonary hypertension can rarely survive to the third decade (1-7). The index case has large inter-atrial and inter-ventricular communications, anterior rudimentary right ventricle and competent left atrioventricular, aortic and pulmonary valves with normal coronary arteries. The exact structural delineation of the heart of the index case was obtained by TTE, in the absence of three-dimensional echocardiography, computed tomography and cardiac magnetic resonance imaging; TTE clearly defined the complex structural cardiac and Doppler features.

This case report documents that a tricuspid atresia patient, with a rare congenital cardiac anatomy, incompatible with longevity without cardiac surgical intervention, was able to survive and function at NYHA I-II, with only the Glen procedure for 18 years, with none of the ventricular, dysrhythmic, systemic, organ dysfunction associated with the Fontan circulation $(3,4)$. Whilst patients' saturations are $90 \%-94 \%$ post Fontan, the index case was of high intellect with a steady state saturation of $74 \%$, indicating that achievement of high intellectual function is not being sacrificed $(3,4)$. This suggests that Glenn only is an alternative procedure that can be used for specific anatomical types of tricuspid atresia, with there being no need to progress to the Fontan (8), which has its well-documented disadvantages, with additional cardiac surgery and associated morbidity and mortality, which is perioperative and intraoperative (3). The asymptomatic course of the index case underscores the importance of sub-pulmonic assisted blood pumping of inferior vena cava flow, which innately she has, and that the Fontan left ventricular systemic ventricle can support the pulmonary venous and inferior vena cava flow, whilst maintaining good systolic and diastolic ventricular function (3). This is the oldest documented case report of tricuspid atresia 18 years post Glen only, with normal superior vena cava flow to right pulmonary artery with respiration, and normal pulmonary blood flow, without development of pulmonary hypertension or other Fontan circulatory dysfunctions.

\section{REFERENCES}

1. Anderson RH, Macartney FJ, Shinebourne EA, Tynan M. Tricuspid atresia. In: Paediatric Cardiology. Vol. 2. New York: Churchill Livingstone Inc; 1987: 675-96.

2. Kirklin JW, Barrett-Boyes BG. Truncus arteriosus. In: Cardiac Surgery. Vol. 2. New York: Churchill Livingstone Inc; 1993: 1131.

3. Mondesert B, Marcotte F, Monegan F-R, Dore A, Mercier L-A, Ibrahim R et al. Fontan circulation: success or failure? Can J Cardiol 2013; 29: 811-20.

4. Niwa K, Perloff JK, Kaplan S, Child JS, Miner PD. Eisenmenger syndrome in adults: ventricular septal defect, truncus arteriosus, univentricular hearts. J Am Coll Cardiol 1999; 34: 223-32.

5. Frescura $\mathrm{C}$, Thiene $\mathrm{G}$. The new concept of univentricular heart. Front Pediatr 2014; 2: 62. doi: 10.3389/fped.2014.00062.

6. Karimi M, Rosenberg CA, Lutin W. Damus-Kaye-Stansel procedure 5 years after Fontan operation with ligated main pulmonary artery. Cardiol Young 2013; 23: 613-6. doi: 10.1017/S1047951112001436.

7. Huang C, Gao L, Zhao T, Xu X, Yang Y. Modified Bjork procedure for tricuspid atresia with pulmonary hypertension. J Card Surg 2011; 26: 657-9.

8. Gewillig M. The Fontan circulation. Heart 2005; 91: 839-46. doi: 10.1136/hrt.2004.051789 